\title{
Pemanfaatan Pupuk Organik Kulit Pisang Dan Azolla Terhadap Pertumbuhan Kangkung Darat Dengan Sistem Akuaponik
}

\author{
Maria Sastriana S. $^{1}$ dan Ngadiani $^{2}$ \\ ${ }^{1}$ Mahasiswa Prodi Biologi Fakultas Matematika dan Ilmu Pengetahuan Alam Universitas \\ PGRI Adi Buana Surabaya \\ Email: sastri23maria@gmail.com \\ ${ }^{2}$ Dosen Program Studi Biologi Fakultas Matematika dan Ilmu Pengetahuan Alam \\ Universitas PGRI Adi Buana Surabaya \\ Email: ngadiani@unipasby.ac.id
}

\begin{abstract}
The aim of this study was to compare the organic fertilizer of azolla pinnata and banana peel and a combination of azolla pinnata and banana peel with the same concentration of $800 \mathrm{ppm}$ to the weight of harvest and the chlorophyll content of ground spinach (Ipomoea reptans Poir.). The experiment was carried out experimentally using a completely randomized design with control treatment, 800 ppm azolla pinnata, 800 ppm banana skin and a combination of azolla pinnata and banana peels 800 ppm which were repeated 6 times each. The application was carried out by pouring 800 ppm of azolla pinnata, 800 ppm of banana peel and a combination of azolla pinnata and 800 ppm banana peel on each gutter. The results showed that azolla pinnata and banana peel nutrition had a significant effect $(P<0.05)$ on harvest weight and chlorophyll content of ground spinach plants (Ipomoea reptans Poir.). Nutrition azolla pinnata and banana peel with a concentration of 800 ppm can increase the weight of the land spinach (Ipomoea reptans Poir.) Which has the highest average. In testing the chlorophyll content, the results of chlorophyll a content, chlorophyll b content and the highest total chlorophyll content was found in azolla pinnata $800 \mathrm{ppm}$ nutrition. The results of this study concluded that $800 \mathrm{ppm}$ azolla pinnata, 800 ppm banana peel and 800 ppm combination of azolla pinnata and banana peel in the growth of ground spinach plants (Ipomoea reptans Poir.) Were effective to increase harvest weight and increase chlorophyll content of land spinach (Ipomoea reptans Poir.) Namely chlorophyll a, chlorophyll $b$ and total chlorophyll of land spinach plants (Ipomoea reptans Poir.).
\end{abstract}

Keywords: ground kale, azolla pinnata, banana peel, harvest weight, test of chlorophyll content, chlorophyll a, chlorophyll b, total chlorophyll.

\section{Pendahuluan}

Kebutuhan

sayuran

kangkung di daerah Jawa Timur cenderung terus meningkat sejalan dengan meningkatnya kesadaran masyarakat akan pentingnya gizi dan banyaknya rumah makan yang menyajikan sayur kangkung sebagai salah satu menu mereka (Departemen Pertanian Provinsi Riau. 2013). Produksi kangkung di daerah Jawa Timur dapat mencapai 50.000-60.000 kg per hektar. Lahan $1 / 4 \mathrm{Ha}$ yang ditanami kangkung 
dalam sekali tanam menghabiskan 5 $\mathrm{kg}$ benih kangkung namun menghasilkan produk yang masih kurang dibanding tanaman lainnya. Dari aspek sosial dan ekonomi, tanaman kangkung darat memiliki prospek yang cukup baik jika dikembangkan ke arah agribisnis. Kangkung darat menempati urutan ke-14 dari 18 jenis sayur di Indonesia (Departemen Pertanian Provinsi Riau. 2013).

Sistem teknologi akuaponik merupakan penggabungan antara sistem akuakultur dan sistem hidroponik. Dalam sistem akuakultur, sumber daya air merupakan hal yang sangat penting. Ketersediaan air secara kuantitatif maupun kualitatif merupakan prasyarat untuk dapat berlangsungnya kegiatan akuakultur. Berdasarkan kadar garamnya (salinitas), perairan dipermukaan bumi dibagi menjadi 3 golongan, yaitu air tawar, air payau, dan air laut. Seiring dengan makin pesatnya laju pembangunan maka salah satu konsekuensi yang harus kita hadapi adalah semakin menyusutnya sumber air, khususnya di daerah perkotaan. Padahal, air menjadi salah satu yang dapat digunakan untuk mendukung aktivitas sehari-hari manusia, salah satunya adalah untuk bidang perikanan. Disamping itu, sistem teknologi akuaponik juga mempunyai keuntungan lainnya berupa pemasukan tambahan dari hasil tanaman yang akan memperbesar keuntungan para peternak ikan (Deustche Welle Indonesia, 2009).

Limbah kulit pisang masih belum mendapatkan penanganan yang cukup karena pada limbah pisang masih mengandung $15 \%$ kalium dan $12 \%$ fosfor lebih banyak dari pada daging buah (Anonim, 2007). Keberadaan kalium dan Fosfor yang cukup tinggi dapat dimanfaatkan sebagai pengganti pupuk. Pupuk kulit buah pisang adalah sumber potensial pupuk potasium dengan kadar $\mathrm{K} 2 \mathrm{O}$ 46-57 \% basis kering. Selain mengandung fosfor dan potasium, kulit pisang juga mengandung unsur magnesium, sulfur dan sodium (Anonim, 2007).

Azolla pinnata merupakan tanaman yang biasa hidup di atas permukaan air. Dapat ditemukan pada semua persawahan di Indonesia. Petani masih banyak yang menganggap tanaman Azolla pinnata sebagai gulma, oleh karena itu pembersihan Azolla pinnata dari lahan persawahan dan kolam merupakan salah satu pekerjaan rutin bagi petani. Azolla pinnata kemudian dibuang begitu saja, atau sebagian diantaranya kemudian digunakan sebagai pupuk hijau bagi tanaman pertanian (Nadiah, 2015).

Berdasarkan uraian di atas, maka peneliti tertarik untuk melakukan penelitian tentang "Pemanfaatan Pupuk Organik Kulit 
Pisang Dan Azolla Terhadap Pertumbuhan Kangkung Darat Dengan Sistem Akuaponik" dilihat dari berat bersih dan kandungan klorofil tanaman Kangkung Darat (Ipomoea reptans Poir.). Penelitian ini bertujuan untuk mengetahui pengaruh pemberian variasi perlakuan dari pupuk organik limbah kulit pisang dan azolla pinnata yang berbeda terhadap pertumbuhan tanaman Kangkung Darat (Ipomoea reptans Poir.) dengan sistem akuaponik dan untuk mengetahui pada perlakuan mana yang dapat memberikan hasil terbaik pada berat basah tanaman Kangkung Darat (Ipomoea reptans Poir.) dan kandungan klorofil tanaman Kangkung Darat (Ipomoea reptans Poir.).

\section{Metode Penelitian}

Jenis penelitian ini adalah penelitian kuantitatif yaitu penelitian yang menekankan pada data-data numerikal (angka) yang diolah dengan metode statistika (Azwar, Saifuddin. 2007). Penelitian ini dilaksanakan dengan metode eksperimen di green house Progam Studi Biologi FMIPA Universitas PGRI Adi Buana Surabaya, menggunakan rancangan acak Lengkap (RAL) karena semua unsur yang tidak diteliti dalam percobaan dibuat sama atau homogen, kemudian diteruskan dengan uji (ANAVA) untuk mengetahui adanya pengaruh yang signifikan, apabila hasil uji ANAVA signifikan maka dilanjutkan uji BNT (Beda Nyata Terkecil) untuk mengetahui perlakuan apa saja yang berbeda nyata antara perlakuan satu dengan yang lainnya. Kemudian dilanjutkan uji Duncan untuk mengetahui perlakuan yang paling optimal atau perlakuan yang terbaik diantara empat perlakuan. Pada penelitian ini menggunakan empat perlakuan dan enam pengulangan yang akan di aplikasikan pada tanaman Kangkung Darat (Ipomoea reptans Poir.). Perlakuan terdiri atas 4 konsentrasi yaitu perlakuan A konsentrasi 0 ppm kontrol (air sumur), perlakuan B konsentrasi 800 ppm dengan azolla pinnata, perlakuan C konsentrasi 800 ppm dengan kulit pisang, perlakuan $\mathrm{D}$ konsentrasi 800 ppm dengan kulit pisang dan Azzola pinnata.

1. Perlakuan $\mathrm{A}=$ air sumur (kontrol)

2. Perlakuan $\mathrm{B}=$ nutrisi azolla pinnata

3. Perlakuan $\mathrm{C}=$ nutrisi kulit pisang

4. Perlakuan $\mathrm{D}=$ nutrisi kombinasi azolla pinnata dan kulit pisang

\section{Waktu dan tempat pelaksanaan}

Penelitian ini akan dilaksanakan mulai bulan MaretMei 2018 yang bertempat di green house Progam Studi Biologi FMIPA 
Universitas PGRI Adi Buana Surabaya.

\section{Alat dan bahan penelitian Alat}

Alat yang digunakan dalam penelitian ini adalah : tangki ikan, netpot atau glas plastik, Talang, Pompa air, Pipa, Kerikil, Selang, ember, bor, lem G, lem silikon, isolasi, gergaji, penggaris, tang, timbangan analitik, kamera, aerator, alat pengukur nutrisi (TD/EC), pengukur $\mathrm{PH}$ ( $\mathrm{PH}$ meter), gunting, timbangan semianalitik, pisau, pipet ukur, pipet tetes, vortex, kuvet, tabung reaksi, botol sampel, stirrer, gelas ukur, mortar, termos es, dan spektrofotometer UV-Vis, alat tulis.

\section{Bahan}

Bahan yang digunakan dalam penelitian ini adalah : bibit kangkung darat, kulit pisang, azolla pinata, ikan nila, tetes tebu, EM4, aseton $80 \%$, aquades, dan kertas saring.

\section{Prosedur Penelitian}

\section{a. Pembuatan Pupuk Organik} Limbah Kulit Pisang dan Azolla pinnata.

Pada pembuatan pupuk organik limbah kulit pisang dan azolla pinnata yang telah dibersihkan. Limbah kulit pisang dan azolla pinnata dipotong kecilkecil masing-masing sebanyak 500 gram dan ditambahkan air sebanyak $1000 \mathrm{ml}$ kemudian di blender hingga halus dan diamkan selama 20 menit agar mikroorgnisme berkembang. Setelah itu tuangkan sedikit EM4 dan tetes tebu sebanyak $100 \mathrm{ml}$ kedalam bahan-bahan yang telah dipersiapkan sebelumnya, campurkan secara merata hingga bahan-bahannya tercampur. Bahanbahan yang telah dicampurkan di fermentasi selama 2 minggu dengan suhu ruangan yaitu sekitar $37^{\circ} \mathrm{C}$, setelah 2 minggu larutan pupuk organik cair sudah siap digunakan.

\section{b. Pembuatan Akuaponik}

Sediakan 4 talang air yang berukuran $1 \mathrm{~m}$ di isi dengan kerikil sampai penuh, 24 netpot yang berisi bibit tanaman kangkung darat yang telah di semai diletakkan dalam media talang (instalasi akuaponik) yang berisi kerikil, setiap talang air berisi 6 bibit kangkung darat. Air yang berasal dari kolam pemeliharaan ikan Nila selanjutnya dialirkan ke media talang air dengan menggunakan pompa aerator.

\section{c. Prosedur Analisis Kandungan Klorofil}

Analisis kandungan klorofil daun diukur dengan menggunakan metode Yoshida et al. (1976) saat tanaman berumur 48 hari. Sampel daun yang digunakan adalah daun ke-3 dari pucuk dengan ibu tulang daun dihilangkan. Daun ditimbang seberat 0,1 gram kemudian digerus dengan mortar dan dilarutkan dalam $10 \mathrm{ml}$ aseton $80 \%$. 
Ekstrak

menggunakan kertas saring. Larutan hasil gerusan dimasukan kedalam tabung reaksi dan ditutup dengan aluminium foil. Untuk pengukuran, larutan klorofil dimasukan ke dalam kuvet diukur pada panjang gelombang 645 dan $663 \mathrm{~nm}$. Kandungan klorofil a, b dan total per $\mathrm{mg} / \mathrm{g}$ berat daun dihitung dengan rumus:

Klorofil $\mathrm{a}=[(12,7$ x A663) - (2,69 x A645)] x 0,1

Klorofil $b=[(22,9 \times$ A645) $-(4,68$ x A663)] x 0,1

Total Klorofil $=[(8,02 \times$ A663 $)+$ (20,2 x A645)] x 0,1

Keterangan:

A663: pembacaan spektrofotometer pada panjang gelombang $663 \mathrm{~nm}$

A645: pembacaan spektrofotometer pada panjang gelombang $645 \mathrm{~nm}$

\section{d. Pengukuran Berat Basah Selada Merah \\ Pada pengukuran berah} basah dapat dilakukan dengan cara menimbang selada merah yang baru saja dipanen ke dalam timbangan analitik kemudian hasil timbangan tersebut dicatat.

\section{Hasil Dan Pembahasan}

\section{Bobot Panen}

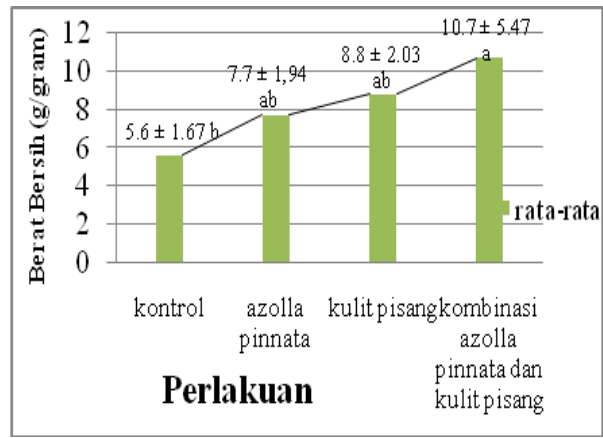

Gambar 1 Berat Bersih Tanaman Kangkung Darat (Ipomoea Reptans Poir.) angka yang diberi huruf (a, b, c, dan d) tidak sama menunjukkan berbeda signifikan $(\mathrm{P}<0,05)$.

Berdasarkan grafik diatas menunjukkan bahwa jumlah ratarata bobot panen pada daun tanaman kangkung darat tertinggi terletak pada perlakuan kombinasi azolla pinnata dan kulit pisang 800 ppm yaitu $(10,7 \pm 5,47$ a). Sedangkan jumlah rata-rata berat bersih pada daun tanaman kangkung darat terendah terletak pada perlakuan kontrol dengan jumlah rata-rata $(5,6$ $\pm 1,67$ b). Jadi, jumlah rata-rata berat bersih pada daun tanaman kangkung darat tertinggi terletak pada perlakuan kombinasi azolla pinnata dan kulit pisang 800 ppm yaitu $(10,7 \pm 5,47$ a). 


\section{Kandungan Klorofil (Klorofil a)}

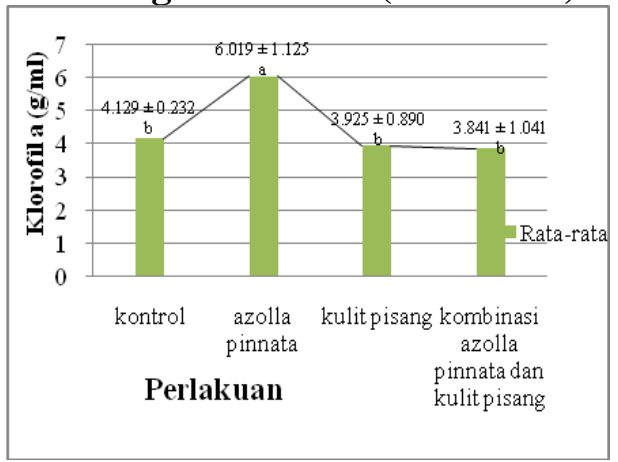

Gambar 2 Rata-Rata Kandungan Klorofil a Tanaman Kangkung Darat (Ipomoea Reptans Poir.) angka yang diberi huruf (a, $\mathrm{b}$, c, dan d) tidak sama menunjukkan berbeda signifikan $(\mathrm{P}<0,05)$.

Berdasarkan grafik diatas menunjukkan bahwa jumlah ratarata kandungan klorofil a pada bagian daun tanaman kangkung darat tertinggi terletak pada perlakuan pemberian nutrisi dari azolla pinnata 800 ppm yaitu (6.019 \pm 1.125). Sedangkan kandungan klorofil a pada bagian daun tanaman kangkung darat terendah terletak pada perlakuan kombinasi azolla pinnata dan kulit pisang dengan jumlah rata-rata $(3.841 \pm 1.041)$. Jadi, kandungan klorofil a pada bagian daun tanaman kangkung darat (Ipomoea Reptans Poir.) yang paling optimal terdapat pada perlakuan pemberian nutrisi dari azolla pinnata 800 ppm (6.019 \pm $1.125)$.

\section{Kandungan Klorofil (Klorofil b)}

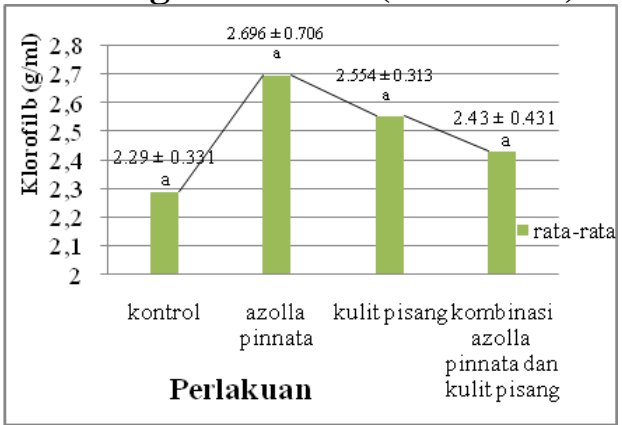

Gambar 3 Rata-Rata Kandungan Klorofil b Tanaman Kangkung Darat (Ipomoea Reptans Poir.), angka yang diberi huruf (a) tidak berbeda signifikan $(\mathrm{P}<0,05)$.

Berdasarkan grafik diatas menunjukkan bahwa jumlah ratarata kandungan klorofil $b$ pada bagian daun tanaman kangkung darat tertinggi terletak pada perlakuan pemberian nutrisi dari azolla pinnata $800 \mathrm{ppm}$ yaitu (2.696 \pm 0.706). Sedangkan rata-rata klorofil $b$ pada bagian daun tanaman kangkung darat terendah terdapat pada perlakuan kontrol dengan jumlah rata-rata $(2.290 \pm 0.331)$. Jadi, kandungan klorofil b pada bagian daun tanaman kangkung darat (Ipomoea Reptans Poir.) yang paling optimal terdapat pada perlakuan pemberian nutrisi dari azolla pinnata 800 ppm (2.696 \pm 0.706) 


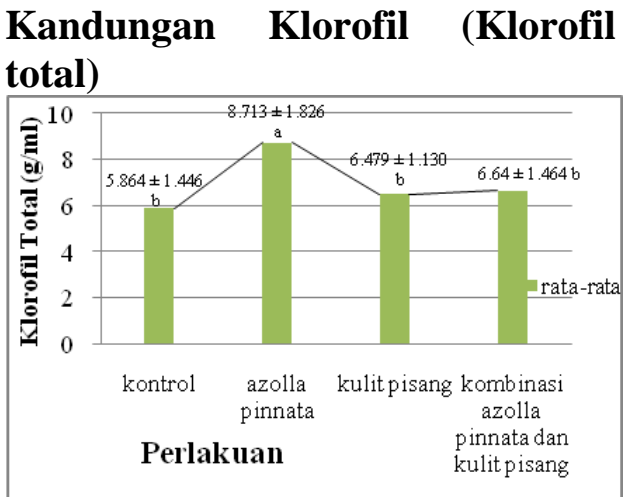

Gambar 4 Rata-Rata Kandungan Klorofil Total Tanaman Kangkung Darat (Ipomoea Reptans Poir.), angka yang diberi huruf (a, b, c, dan d) tidak sama menunjukkan berbeda signifikan $(\mathrm{P}<0,05)$.

Berdasarkan grafik diatas menunjukkan bahwa jumlah ratarata kandungan klorofil total pada bagian daun tanaman kangkung darat tertinggi terletak pada perlakuan pemberian nutrisi dari azolla pinnata 800 ppm yaitu (8.713 \pm 1.826). Sedangkan rata-rata klorofil total pada bagian daun tanaman kangkung darat terendah terdapat pada perlakuan kontrol dengan jumlah rata-rata (5.864 \pm 1.446). Jadi, kandungan klorofil b pada bagian daun tanaman Kangkung Darat (Ipomoea Reptans Poir.) yang paling optimal terdapat pada perlakuan pemberian nutrisi dari azolla pinnata 800 ppm (8.713 \pm 1.826 ).
Pembahasan

a. Bobot Panen Tanaman

Kangkung Darat (Ipomoea reptans Poir.) yang diberikan Nutrisi Dari Azolla pinnata dan Kulit Pisang dengan Sistem Akuaponik

Hasil pengukuran bobot panen kangkung darat didapatkan hasil rata-rata bobot tertinggi terletak pada perlakuan kombinasi Azolla pinnata dan kulit pisang karena kandungan unsur yang ada dalam azolla pinnata dan kulit pisang sudah dapat memenuhi kebutuhan tanaman kangkung darat (Ipomoea reptans Poir.). Pertumbuhan dan perkembangan kangkung darat (Ipomoea reptans Poir.) selain dipengaruhi oleh nutrisi azolla pinnata dan kulit pisang dapat juga dipengaruhi oleh faktor eksternal yang berpengaruh dari kondisi lingkungan yang terdiri dari cahaya, suhu, kelembaban udara, angin, oksigen dan air. Faktor-faktor tersebut seragam disetiap perlakuan dan saling berhubungan satu dengan yang lainnya. Apabila salah satu faktor tersebut tidak tersedia bagi tanaman kangkung darat (Ipomoea reptans Poir.) dan ketersediaanya tidak seimbang dengan faktor lainnya, maka faktor tersebut dapat menghentikan pertumbuhan tanaman kangkung darat (Ipomoea reptans Poir.) itu sendiri. Dalam penelitian Sriharti (2008), menerangkan bahwa limbah kulit pisang merupakan substansi organik 
dengan kandungan Nitrogen sebesar $35 \%$ yang berguna sebagai penggembur. Kandungan gizi dalam kulit pisang berpotensi sebagai sumber mikroorganisme lokal karena kandungan gizi dalam kulit pisang dapat digunakan sebagai sumber makanan sehingga mikroba berkembang dengan baik untuk memperbaiki perakaran sehingga mempengaruhi penyerapan hara. Hasil penelitian Indrasari dan Syukur (2006), menunjukkan bahwa pemberian nutrisi azolla pinnata dapat meningkatkan meningkatkan berat bersih tanaman kangkung darat menjadi lebih tinggi. Sedangkan pada perlakuan pemberian nutrisi dari azolla pinnata yang memiliki bobot tanaman kangkung darat (Ipomoea reptans Poir.) paling rendah. Hal ini bisa terjadi akibat kandungan nutrisi yang terdapat pada azolla pinnata masih belum memenuhi kebutuhan unsur hara yang dibutuhkan dalam pertumbuhan tanaman kangkung darat (Ipomoea reptans Poir.).

Tanaman

dalam

pertumbuhannya memerlukan zatzat makanan atau unsur hara yang terdiri dari unsur hara makro dan unsur hara mikro. Unsur hara makro adalah unsur hara yang dibutuhkan oleh tanaman dalam jumlah besar, yang termasuk unsur hara makro adalah $\mathrm{N}, \mathrm{P}, \mathrm{K}, \mathrm{S}, \mathrm{Mg}$ dan $\mathrm{Ca}$. Unsur hara mikro adalah unsur hara yang dibutuhkan oleh tanaman dalam jumlah kecil/sedikit, yang termasuk unsur hara mikro adalah $\mathrm{Fe}, \mathrm{Cu}, \mathrm{Zn}, \mathrm{Mn}, \mathrm{Mo}, \mathrm{B}, \mathrm{Na}$, $\mathrm{Cl}$. Kebutuhan unsur hara ini mutlak bagi setiap tanaman dan tidak bisa digantikan oleh unsur yang lain tentunya dengan kadar yang berbeda sesuai jenis tanamannya sebab jika kekurangan unsur hara akan menghambat pertumbuhan tanaman itu sendiri (Akbari, 2015). Unsurunsur tersebut dibutuhkan tanaman karena mempunyai fungsi sendirisendiri dalam membantu kelangsungan hidup tanaman.

\section{b. Kandungan Klorofil Kangkung Darat (Ipomoea Reptans Poir.) Yang Diberikan Nutrisi Dari Azolla Pinnata Dan Kulit Pisang Dengan Sistem Akuaponik}

Klorofil merupakan sebagian besar pigmen yang ditemukan dalam membran tilakoid kloroplas. Pigmen hijau pada daun berperan mengabsorpsi cahaya dalam fotosintesis fase I, yaitu reaksi fotolisis. Pigmen klorofil tidak hanya berperan sebagai pigmen fotosintesis, tetapi juga bermanfaat sebagai obat kanker otak dan paruparu. Klorofil juga dapat digunakan sebagai desinfektan, antibiotik dan food supplement. Klorofil dapat digunakan sebagai food supplement (makanan tambahan) karena mengandung nutrisi yang dibutuhkan untuk tubuh manusia (Abdilah, 2014). Klorofil juga merangsang pembentukan darah 
karena menyediakan bahan dasar dari pembentuk hemoglobin. Sumber klorofil di Indonesia sangat melimpah, tetapi pemanfaatan klorofil di Indonesia masih sangat minim (Abdilah, 2014).

Berdasarkan hasil penelitian yang telah dilakukan menunjukkan bahwa perlakuan pemberian pupuk organik cair dari bahan baku azolla pinnata dan kulit pisang berpengaruh signifikan $(\mathrm{P}<0,05)$ terhadap kandungan klorofil a, kandungan klorofil $b$, dan kandungan klorofil total Kangkung Darat (Ipomoea Reptans Poir.) Hal ini terbukti dengan adanya jumlah rata-rata tertinggi klorofil a, klorofil b dan klorofil total terletak pada perlakuan pemberian nutrisi dari 800 ppm azolla pinnata. Hasil penelitian Aksan (2013) mengatakan bahwa pemberian nutrisi azolla pinnata dapat meningkatkan tinggi tanaman, jumlah daun, luas daun, panjang akar, berat segar tanaman, dan berat segar akar tanaman kangkung darat (Ipomoea reptans Poir.) yang baik dan optimal. Pemberian azolla pinnata, unsur hara belum tersedia pada saat tanaman kangkung darat (Ipomoea reptans Poir.) membutuhkan unsur hara tersebut, karena salah satu sifat dari pupuk organik adalah slow release, artinya diperlukan waktu untuk mengalami proses dekomposisi sebelum dapat digunakan oleh tanaman kangkung darat (Ipomoea reptans Poir.) sehingga unsur hara yang dikandung oleh azolla pinnata belum dapat dimanfaatkan semaksimal mungkin oleh tanaman kangkung darat (Ipomoea reptans Poir.). Pelepasan unsur hara yang tidak sinkron menyebabkan kehilangan atau defisit unsur hara.

Tanaman azolla pinnata memiliki kemampuan untuk dijadikan sebagai pupuk organik karena didalamnya mengandung beberapa unsur salah satunya unsur $\mathrm{N}$. Kandungan $\mathrm{N}$ yang tinggi dalam tanaman azolla pinnata diduga dapat meningkatkan kandungan klorofil dari tanaman Kangkung Darat (Ipomoea Reptans Poir.). Hal ini dapat dilihat pada beberapa sampel Kangkung Darat (Ipomoea Reptans Poir.) yang diberi nutrisi dari pupuk organik $800 \mathrm{ppm}$ azolla pinnata dan 800 ppm kulit pisang. Seperti yang terlihat pada pengolahan data bahwa rata-rata klorofil a, klorofil b dan klorofil total tertinggi terletak pada perlakuan pemberian pupuk organik dari 800 ppm azolla pinnata. Menurut Sunarjono (2014) kandungan klorofil yang lebih tinggi mampu menghasilkan karbohidrat atau asimilat dalam jumlah yang tinggi untuk menopang pertumbuhan vegetatif.

\section{Simpulan dan Saran}

\section{Simpulan}

1. Dari hasil penelitian dapat disimpulkan bahwa ada 
pengaruh nyata setelah pemberian nutrisi dari pupuk organik cair kulit pisang dan azolla pinnata terhadap pertumbuhan tanaman kangkung darat (Ipomoea reptans Poir.) dengan sistem akuaponik.

2. Dari hasil penelitian dapat disimpulkan pemberian nutrisi azolla pinnata $800 \mathrm{ppm}$ berpengaruh signifikan pada uji kandungan klorofil kangkung darat (Ipomoea reptans Poir.) yaitu klorofil a, klorofil $b$ dan klorofil total.

\section{Saran}

Penelitian menyarankan bahwa azolla pinnata dan limbah kulit pisang dapat dijadikan sebagai media pengganti pupuk organik cair untuk pertumbuhan kangkung darat (Ipomoea reptans Poir.) dengan konsentrasi $800 \mathrm{ppm}$ azolla pinnata dan limbah kulit pisang untuk menghasilkan berat bersih dan kandungan klorofil a, klorofil $\mathrm{b}$ dan klorofil total yang baik.

\section{Daftar Pustaka}

Abdilah et al., 2014. Pegujian Daya Antioksidan dan Sifat Toksisitas Ekstrak Co (II) Turunan Klorofil [Artikel ilmiah]. Jurusan Kimia FMIPA Universitas Hasanuddin. Makasar.

Akbari. A., dkk. 2015. Pemanfaatan Limbah Kulit Pisang. Jurnal Skripsi. Fakultas Teknik
Universitas Tanjungpura, Pontianak.

Aksan, 2013. Kajian Pemanfaatan Kompos Azolla pinnata Guna Mereduksi Dosis Pupuk Nitrogen Anorganik Pada Budidaya kangkung darat (Ipomoea reptans Poir.) Program Studi Agroteknologi Fakultas Pertanian UMY. Skripsi. Yogyakarata: Universitas Muhammadiyah Yogyakarta

Anonim. 2007. Pisang. Http : // www. wiki pedia. com. Diakses tanggal 14 Januari 2018.

Azwar, Saifuddin. 2007. Metode Penelitian. Pustaka Pelajar: Yogyakarta.

Departemen Pertanian Provinsi Riau. 2013. Produksi Tanaman Kangkung. Departemen Pertanian Provinsi Riau. Pekanbaru.

Deustche Welle Indonesia, 2009. Pertanian Akuaponik Modern. Sains dan Teknologi Deustche Welle Indonesia. htn Diakses 23 Januari 2018.

Nadiah, A. 2015. Prospek Azolla sebagai Pupuk Hijau Penghasil Nitrogen. ditjenbun.pertanian.go.id.diaks es tanggal 14 Januari 2018.

Sunarjono, H.H. 2014. Bertanam 36 Jenis Sayuran Jakarta : Penebar Swadaya 